\title{
Meiotic behavior of interspecific hybrids between artificially tetraploidized sexual Brachiaria ruziziensis and tetraploid apomictic $B$. brizantha (Poaceae)
}

\author{
Mariana Ferrari Felismino ${ }^{1}$; Maria Suely Pagliarini ${ }^{1 *}$; Cacilda Borges do Valle ${ }^{2}$ \\ ${ }^{1}$ UEM - Depto. de Biologia Celular e Genética, Av. Colombo, 5790, Zona 7 - 87020-900 - Maringá, PR - Brasil. \\ ${ }^{2}$ Embrapa Gado de Corte, C.P. 154 - $79002-970$ - Campo Grande, MS - Brasil. \\ *Corresponding author <mspagliarini@uem.br>
}

\begin{abstract}
The meiotic behavior of four interspecific promising hybrids was evaluated by conventional cytological methods. The female genitors were two artificially tetraploidized sexual accessions of $B$. ruziziensis (R41 and $\mathrm{R} 44,2 \mathrm{n}=4 \chi=36$ ), which were crossed to an agronomically superior natural tetraploid apomictic genotype of $B$. brizantha (B140 - BRA003395). Three of them (HBGC313, HBGC 315, and HBGC324) were sexual and one (HBGC325) apomictic. Analyses of some cells in diakinesis revealed multivalent chromosome configurations, suggesting that genetic recombination and introgression of some genes could be present. The four hybrids had different types of meiotic abnormalities at various frequencies. Abnormalities related to irregular chromosome segregation due to polyploidy were common among these hybrids, and characterized by precocious chromosome migration to the poles, laggard chromosomes, both generating micronuclei in telophases and tetrads and, as a consequence, unbalanced gametes. One abnormality genotype-specific, related to spindle orientation (a putative divergent spindle mutation), was recorded for the first time in two of the hybrids, HBGC313 and HBGC325. The sexual hybrid HBGC324 had the lower rate of abnormalities, and it could be used as a female genitor in future crosses in the breeding program. The abnormalities present in these hybrids may impact fertility and affect seed production. Based on the results, HBGC324 is the single hybrid recommended to the breeding program. Hybrids must produce a good amount of viable seeds, besides good overall dry matter production and nutritive value, in order to be widely utilized and adopted in production systems. Due to pseudogamy, the desirable superior apomictic hybrids need viable pollen grains to fertilize the secondary nucleus of the embryo sac and thus ensure normal and vigorous endosperm development and plenty of seed set.
\end{abstract}

Key words: Brachiaria, Brazil, cytogenetics, forage grasses, meiosis

\section{Comportamento meiótico de híbridos interespecíficos entre tetraplóides artificiais de Brachiaria ruziziensis e tetraplóides apomíticos de B. brizantha (Poaceae)}

\begin{abstract}
RESUMO: O comportamento meiótico de quatro híbridos interespecíficos promissores de Brachiaria foi avaliado por metodologia citogenética convencional. Os genitores femininos eram dois acessos sexuais tetraploidizados artificialmente de $B$. ruziziensis ( $\mathrm{R} 41$ e $\mathrm{R} 44,2 \mathrm{n}=4 \chi=36$ ), os quais foram cruzados com um genótipo tetraplóide natural apomítico agronomicamente superior de B. brizantha (B140 - BRA003395). Três deles (HBGC313, HBGC 315 e HBGC324) eram sexuais e um (HBGC325) apomítico. A análise de algumas células em diacinese revelou a presença de configurações cromossômicas multivalentes, sugerindo que recombinação genética e introgressão de alguns genes poderão estar presentes. Os quatro híbridos apresentaram freqüências e tipos variados de anormalidades meióticas. Anormalidades relacionadas à segregação irregular de cromossomos devido à poliploidia foram comuns entre os híbridos e caracterizadas pela presença de cromossomos em ascensão para os pólos e cromossomos retardatários, ambos levando à formação de micronúcleos em telófases e tétrades e, como conseqüência, gametas desbalanceados. Uma anormalidade genótipo-específica, relacionada à orientação do fuso (uma possível mutação fuso divergente) foi observada pela primeira vez em dois dos híbridos, HBGC313 e HBGC325. O híbrido sexual HBGC324 apresentou menor freqüência de anormalidades meióticas, podendo ser usado como genitor feminino em futuros cruzamentos no programa de melhoramento. A frequência e os tipos de anormalidades observadas podem afetar a fertilidade e a produção de sementes. Com base nos resultados, o híbrido HBGC324 é recomendado para o programa de melhoramento. Híbridos devem produzir grande quantidade de sementes viáveis, além de matéria seca com alto valor nutritivo para serem amplamente utilizados na produção de pastagens. Devido à pseudogamia, os híbridos apomíticos superiores necessitam de grãos de pólen viáveis para fertilizar o núcleo secundário do saco embrionário assegurando o desenvolvimento vigoroso do endosperma e a produção de sementes.
\end{abstract}

Palavras-chave: Brachiaria, Brasil, citogenética, meiose, forrageira

Sci. Agric. (Piracicaba, Braz.), v.67, n.2, p.191-197, March/April 2010 


\section{Introduction}

In the last decades, Brazil became the largest beef cattle producer and exporter of beef products. Tropical humid climate and extensive almost flat terrain provide the natural conditions for year-round beef production on cultivated pastures. Brachiariagrass alone accounts for $85 \%$ of the cultivated pastures in Brazil, covering over 80 million hectares and sustaining the largest commercial herd in the world - about 205 million of heads. The genus Brachiaria has great success as a forage grass in the South American savannas due to its physiological tolerance to the typical low-fertility acid soils of the tropics (Rao et al., 1996). The most widely grown species of forage grass in the Brazilian savannas and throughout the tropics are $B$. decumbens cv. Basilisk and $B$. brizantha cv. Marandu. However, the lack of options to diversity pastures is a constraint since cv. Basilisk lacks resistance to a ubiquitous family of sucking insects, the spittlebugs, and cv. Marandu, while quite resistant, requires higher soil fertility (Miles et al., 1996) and is unsuitable for poorly-drained soils, especially in the Amazon region where large areas of dying pastures are reported (Barbosa, 2006).

Pasture renovation and intensification of beef production demand new improved cultivars, which can be obtained by selection from native germplasm or generated in breeding programs. The brachiariagrass breeding programs were delayed because the most important accessions and cultivars are polyploid $(2 \mathrm{n}=4 \chi=36)$ and apomictic (Valle and Savidan, 1996). Brachiaria breeding became effective only when a suitable sexual germplasm was artificially developed in 1980s. Brachiaria ruziziensis (ruzigrass) is a natural, sexual diploid species. Accessions of this species were tetraploidized with colchicine in Belgium (Swenne et al., 1981; Gobbe et al., 1981) and maintained the sexuality necessary for hybridization with apomictic natural tetraploid accessions. These materials have allowed apomixis to be exploited in the breeding of Brachiaria.

The main objective of the Brachiaria program in tropical America is to use the sexuality of the tetraploid ruzigrass to release the genetic diversity locked in the natural tetraploid apomictics such as $B$. brizantha (palisadegrass), and $B$. decumbens (signalgrass), to produce novel apomictic hybrid cultivars (Valle and Savidan, 1996; Miles and Valle, 1996; Miles et al., 2004). In 1988, the Embrapa Beef Cattle Center initiated an extensive program based on interspecific hybridization with the objective of determining the inheritance of apomixis and thus manipulating this character for the development of new improved hybrids. Firstly, the crosses were preferentially done between sexual accessions of $B$. ruziziensis and natural apomictic B. brizantha cv. Marandu or $B$. decumbens cv. Basilisk. Afterwards, other accessions of superior agronomic performance and resistant to splittebugs, such as B. brizantha B140 (BRA003395), were crossed as pollen donors. Hundreds of hybrids were ob- tained from the crosses and 88 selected based on the leafiness and regrowth ability after cuts are under agronomic evaluation. However, besides resistance to splittebugs and adaptation to low fertility soils, a new cultivar needs to have high seed production to meet the internal market demand and also for export.

Cultivars commercially available are direct selections from the natural genetic variability (Miles et al., 2004), except for one interspecific hybrid (cv. 'Mulato'), which produces seeds with viability rate of $10 \%$, thus compromising the commercial interests of the seed industry and impairing wide adoption. Among several factors that could compromise seed viability, Hopkinson et al. (1996) cite interspecific hybridization per se, and the polyploid nature of genotypes, which impair seed viability by affecting pollen fertility. Previous cytogenetical analyses performed on some Brachiaria hybrids produced by Embrapa Beef Cattle (Risso-Pascotto et al., 2005a; Fuzinatto et al., 2007; Adamovski et al., 2008) revealed different types and varying frequencies of meiotic abnormalities, thus indicating the possibility of selecting genotypes for higher pollen viability and, probably, higher seed production. This paper describes the meiotic behavior of four promising hybrids between $B$. ruziziensis and B. brizantha; also, based on the types and frequencies of abnormalities, it gives an indication about the hybrid that is more stable to ensure greater pollen fertility and success in the hybridizations.

\section{Material and Methods}

\section{Plant Material}

Cytological studies were carried out on four interspecific hybrids between $B$. ruziziensis and B. brizantha obtained at Embrapa Beef Cattle, Campo Grande, State

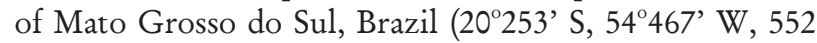
$\mathrm{m}$ altitude). Crosses were manually performed, using pollen from cut inflorescences of the apomictic genitor collected in petri dishes into flowers of the sexual genitors in vases, in the greenhouse. Seeds obtained were individually germinated in Styrofoam trays, and then transplanted to the field as a progeny test. The genitors were two artificially tetraploidized sexual accessions of B. ruziziensis ( $\mathrm{R} 41$ and $\mathrm{R} 44,2 \mathrm{n}=4 \chi=36$ ), (Swenne et al., 1981; Gobbe et al., 1981) and the natural tetraploid apomictic genotype: B. brizantha (B140 - BRA003395, 2n $=4 \chi=36$ ). Two hybrids (HBGC313 and HBGC315) are full-sibs, and the hybrids HBGC324 and HBGC325 are half-sibs to the former two.

Table 1 shows the hybrids, their genitors, and mode of reproduction previously determined by analysis of the embryo-sac types using interference contrast microscopy on methylsalicilate-cleared ovaries (Young et al., 1979). The hybrid nature of these plants was easily identified by their intermediate, morphology between the two parental types: B140 is a tall, erect plant with large, almost glabrous leaves and inflorescences with narrow rachis and one row of spiklets whereas R44 and R41 are typical $B$. ruziziensis plants, short with stoloniferous growth, 
Table 1 - Description of the Brachiaria hybrids, genitors, and mode of reproduction.

\begin{tabular}{lcccc}
\hline Hybrid & Female genitor & Male genitor & Plant & Mode of reproduction* \\
\hline HBGC313 & R41 & B140 (BRA003395) & 13 & Sexual \\
HBGC315 & R41 & B140 (BRA003395) & 18 & Sexual \\
HBGC324 & R44 & B140 (BRA003395) & 4 & Sexual \\
HBGC325 & R44 & B140 (BRA003395) & 5 & Apomictic \\
\hline
\end{tabular}

*Determined by microscope analysis of the type of the embryo sacs within cleared ovaries

hairy decumbent leaves and inflorescences with wide rachis and two rows of spiklets. These hybrids are very vigorous with excellent forage phenotypes (medium growth with a high percentage of leaves) and thus were included in a small plot agronomical evaluation

\section{Cytological Analyses}

Inflorescences in ideal stage for meiotic studies were collected from individual plants growing in the field, fixed in ethanol 95\%, chloroform and propionic acid $(6: 3: 2, \mathrm{v} / \mathrm{v})$ during $24 \mathrm{~h}$ and stored at $4^{\circ} \mathrm{C}$. Anthers containing microsporocytes were isolated from the flowers and slides containing cells spreads were obtained after squashing and stained with $0.5 \%$ propionic carmine. A total of $2457,3147,3051$, and 2374 pollen mother cells (PMCs) were analyzed in the hybrid HBGC313, HBGC315, HBGC324, and HBGC325, respectively. Images were obtained using Kodak Imagelink - HQ, ISO 25 black and white film.

\section{Results and Discussion}

Gene introgression is possible through meiotic recombination. Analyses of diakinesis organization in the four hybrids revealed multivalent chromosome configurations ranging from one to three quadrivalents in some meiocytes (Figure $1 \mathrm{a}, \mathrm{b}$ ). However, in the majority of meiocytes, chromosomes paired as 18 bivalents of the same genome. Chromosome pairing in hybrids is used as a method of assessing the genomic relationship between species (Alonso and Kimber, 1981) and also providing an important starting point in alien introgression programs (Gale and Miller, 1987).

The degree of differentiation between hybridizing taxa can be estimated not only by analyses of chromosome pairing, but also by meiotic abnormalities (Rieseberg et al., 2000). Despite the phylogenetic proximity between B. ruziziensis and B. brizantha (Renvoize et al., 1996), the four hybrids presented different frequencies and types of meiotic abnormalities (Table 2). Although some abnormalities were common among hybrids, others were genotype-specific. Irregular chromosome segregation was recorded among the four hybrids at different frequencies. These were characterized by precocious chromosome migration to the poles in metaphase I (Figure $1 \mathrm{c}, \mathrm{d}$ ) and metaphase II (Figure 1 g); laggard chromosomes in anaphase I (Figure 1 e) and anaphase II, leading to micronuclei formation in telophase I (Figure $1 \mathrm{f}$ ), telophase II (Figure $1 \mathrm{~h}$ ) and in tet- rads (Figure $1 \mathrm{i}-\mathrm{k}$ ), or generating microcytes in tetrads (Figure $1 \mathrm{k}, 1$ ). The HBGC324 was the hybrid that showed the lower rate of irregularities; only $18.2 \%$ of the meiocytes analyzed (3051) showed meiotic abnormalities. Irregular chromosome segregation is the most common meiotic abnormality recorded in Brachiaria hybrids (Lutts et al., 1991; Risso-Pascotto et al., 2005a; Fuzinatto et al., 2007; Adamowski et al., 2008) and such abnormalities are consequences of the interspecies hybridization and polyploidy.

Other meiotic abnormalities here found, such as chromosome stickiness, abnormal cytokinesis, and absence of cytokinesis are also reported for other Brachiaria hybrids (Risso-Pascotto et al., 2005a, Fuzinatto et al., 2007) and among accessions of different species of Brachiaria (Mendes-Bonato et al., 2001a,b; 2002a,b; Risso-Pascotto et al., 2005a,b; Utsunomiya et al., 2005), suggesting that the genes controlling these characters are in the gene pool of the genus. One abnormality, however, was recorded for the first time during the present study in two of the hybrids, HBGC313 and HBGC325. Similar abnormality had been widely reported in maize (Clark, 1940; Staiger and Cande, 1990; Shamina et al., 2000) and it was designated divergent spindle $(d v)$, a putative mutation that affects the orientation of spindle fibers (Figure 2).

In normal microsporocytes, spindle converges to form focused poles, whilst bivalents occupy a small portion in the center of the metaphase plate and the telophase nuclei are spherical (Figure 1). In the microsporocytes here analyzed showing to be affected by the putative $d v$ mutation, bivalents were regularly co-oriented at metaphase plate, although distantly positioned and spread over the equatorial plate (Figure 2 a). Since the spindle fiber did not converge into focused poles in anaphase I, the segregated chromosomes remained parallel and failed to converge at the poles (Figure $2 \mathrm{~b}$ ). As a consequence, telophase I nuclei were fusiform (Figure $2 \mathrm{c}$ ), the genome was grouped into two (Figures $2 \mathrm{~d}$, e) or more micronuclei of different sizes formed in each pole. After this stage, the first cytokinesis occurred and divided the meiocyte into as many cells as the number of telophase nuclei and/or micronuclei formed. The second meiosis progressed normally and the number of chromosomes in each metaphase plate was variable depending on the size of telophase I micronuclei (Figures $2 \mathrm{f}-\mathrm{i})$. Sister-chromatids normally segregated in anaphase II, giving rise to tetrads, hexads (Figure $2 \mathrm{j}$ ) or octads (Figures $2 \mathrm{l}, \mathrm{k}$ ), depending on the number of nuclei and/or micronuclei formed in the first division. The 


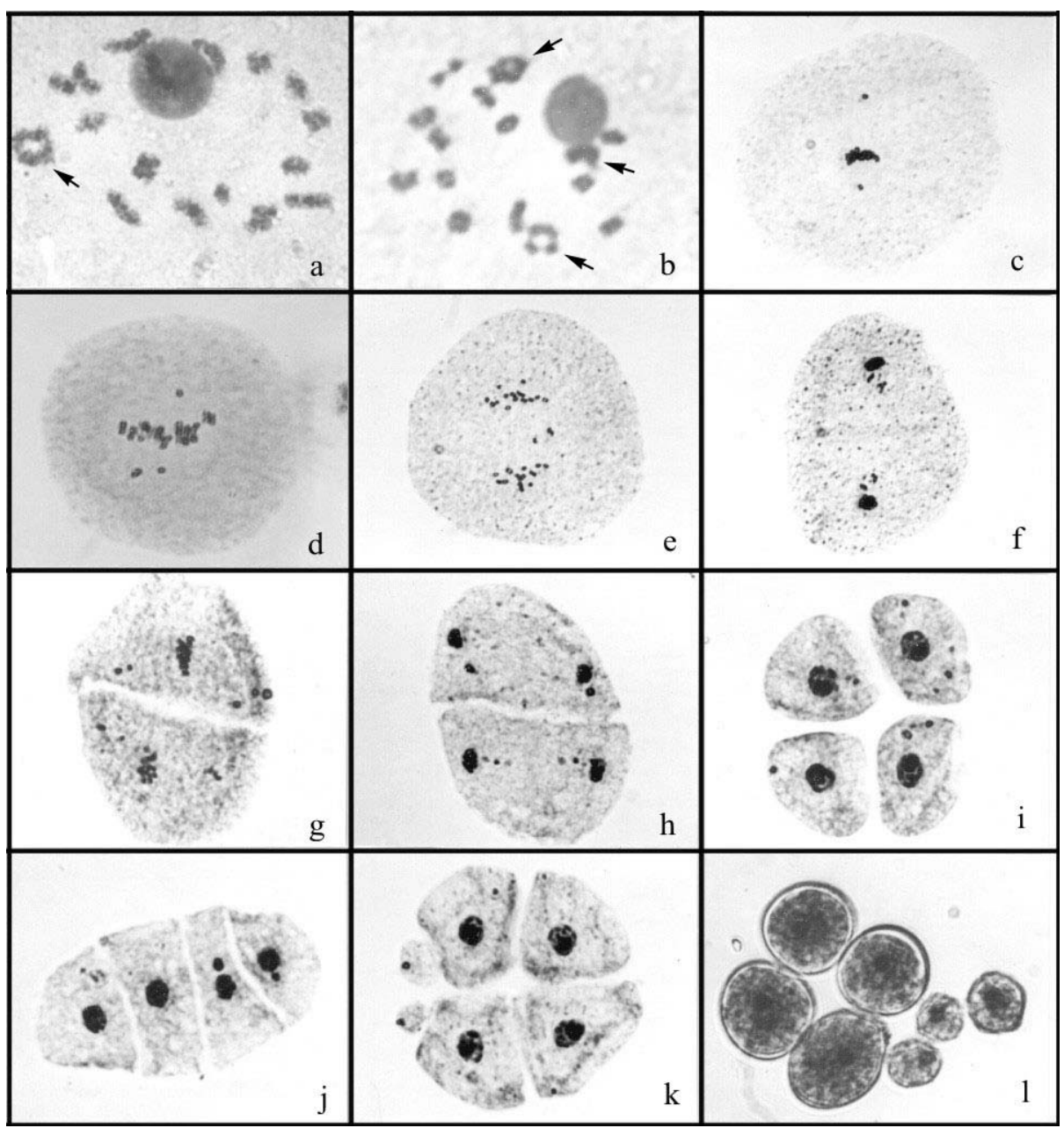

Figure 1 - Aspects of irregular chromosome segregation in the four interspecific hybrids. a, b) Diakinesis with 16 bivalents and one quadrivalent (a), and 12 bivalents and 3 quadrivalents (b), (arrows). (1000X). c, d) Metaphase I with precocious chromosome migration to the poles. e) Anaphase I with laggard chromosomes. f) Telophase I with micronuclei. g) Metaphase II with precocious chromosome migration to the poles. h) Telophase II with micronuclei. i) Isobilateral tetrad with micronuclei in all microspores. j) Linear tetrad with micronuclei. k) Tetrad with microcytes and micronuclei. 1) Pollen grains with different sizes. (400X).

percentage of affected cells by $d v$ varied between the two hybrids and HBGC 325 showed to be more affected than HBGC313 (Table 2).

The abnormalities caused by this putative gene $(d v)$ in addition to the irregular chromosome segregation due to polyploidy present in Brachiaria hybrids caused enough irregularities that constrain the use of those hybrids in the breeding program. In HBGC 313 , the rate of abnormal meiocytes was $55.6 \%$, whilst in the HBGC325 was $46.1 \%$. Hybrid HBGC315 also showed a high rate of abnormalities (48.3\%) although characterized only by irregular chromosome segregation. The more stable hybrid analyzed was the HBGC324 with only $18.2 \%$ of abnormal cells. This hybrid reproduces sexually and therefore, it could be used in crosses with other apomictic genotypes to produce new hybrids.

Crosses between sexual and apomictic plants segregated 1:1 for the reproductive mode (Valle and Savidan, 1996; Savidan, 2000), suggesting a monogenic inheritance of apomixis in Brachiaria and similarly determined for Panicum maximum (Savidan, 2000). Among the four selected promising hybrids, only HBGC325 is apomictic, and it can be used for seed production since megasporogenesis is dependent of male meiosis (Araújo et al., 2000). These plants, nonetheless, are pseudogamous (Alves et al., 2001), thus microsporogenesis will be affected by abnormalities, and pollen fertility may decrease.

At the moment, the Brachiaria breeding program aims at producing apomictic cultivars since selected traits will breed true, i.e., will not segregate, and it will contribute to establish homogeneous improved pastures. Nevertheless, superior sexual hybrids need to be included in the program, acting as female genitors in polycross blocks in order to pyramidize desirable alleles, introgress desirable genes and also to broaden the genetic base of the program. Among the four hybrids analyzed, the sexual HBGC313 and the apomictic HBGC325 should be discarded because the high frequency of the putative muta- 
Table 2 - Frequencies of meiotic abnormalities in the four Brachiaria hybrids.

\begin{tabular}{|c|c|c|c|c|c|c|c|c|c|}
\hline \multirow{3}{*}{ Stage* } & \multirow{3}{*}{ Abnormalities } & \multirow{2}{*}{\multicolumn{2}{|c|}{$\begin{array}{c}\text { HBGC313 } \\
\text { R41 x B140/13 } \\
\text { Sexual }\end{array}$}} & \multicolumn{2}{|c|}{$\begin{array}{c}\text { HBGC315 } \\
\text { R41 x B140/18 }\end{array}$} & \multicolumn{2}{|c|}{$\begin{array}{c}\text { HBGC324 } \\
\text { R44 x B140/4 }\end{array}$} & \multirow{2}{*}{\multicolumn{2}{|c|}{$\begin{array}{c}\text { HBGC325 } \\
\text { R44 x B140/5 }\end{array}$}} \\
\hline & & & & & & & & & mictic \\
\hline & & $\begin{array}{l}\text { No. of } \\
\text { PMCs** } \\
\text { Analyzed }\end{array}$ & $\begin{array}{l}\text { No. of } \\
\text { abnormal } \\
\text { PMCs }\end{array}$ & $\begin{array}{l}\text { No. of } \\
\text { PMCs } \\
\text { analyzed }\end{array}$ & $\begin{array}{l}\text { No. of } \\
\text { abnormal } \\
\text { PMCs }\end{array}$ & $\begin{array}{l}\text { No. of } \\
\text { PMCs } \\
\text { analyzed }\end{array}$ & $\begin{array}{l}\text { No. of } \\
\text { abnormal } \\
\text { PMCs }\end{array}$ & $\begin{array}{l}\text { No. of } \\
\text { PMCs } \\
\text { analyzed }\end{array}$ & $\begin{array}{l}\text { No. of } \\
\text { abnormal } \\
\text { PMCs }\end{array}$ \\
\hline MI & $\begin{array}{l}\text { Precocious } \\
\text { migration }\end{array}$ & 486 & 140 & 652 & 134 & 753 & 54 & 776 & 83 \\
\hline \multirow{3}{*}{ AI } & $\begin{array}{l}\text { Laggard } \\
\text { chromosomes }\end{array}$ & 169 & 110 & 257 & 152 & 278 & 62 & 209 & 38 \\
\hline & $\begin{array}{l}\text { Chromosome } \\
\text { stickiness }\end{array}$ & & 8 & & - & & - & & - \\
\hline & Divergent spindle & & 16 & & - & & - & & 82 \\
\hline \multirow{4}{*}{ TI } & Micronuclei & 460 & 254 & 396 & 222 & 515 & 47 & 394 & 55 \\
\hline & $\begin{array}{l}\text { Chromosome } \\
\text { stickiness }\end{array}$ & & 14 & & - & & 12 & & - \\
\hline & $\begin{array}{l}\text { Abnormal } \\
\text { cytokinesis }\end{array}$ & & - & & - & & 19 & & - \\
\hline & Divergent spindle & & 5 & & - & & - & & 70 \\
\hline \multirow{5}{*}{ PII } & Micronuclei & 449 & 267 & 235 & 138 & 305 & 57 & 482 & 35 \\
\hline & $\begin{array}{l}\text { Chromosome } \\
\text { stickiness }\end{array}$ & & 13 & & - & & - & & - \\
\hline & $\begin{array}{l}\text { Absence of } \\
\text { cytokinesis }\end{array}$ & & 8 & & - & & - & & 14 \\
\hline & $\begin{array}{l}\text { Abnormal } \\
\text { cytokinesis }\end{array}$ & & - & & - & & 19 & & - \\
\hline & Divergent spindle & & 19 & & - & & - & & 341 \\
\hline \multirow{3}{*}{ M II } & $\begin{array}{l}\text { Precocious } \\
\text { migration }\end{array}$ & 177 & 58 & 187 & 47 & 311 & 50 & 216 & 10 \\
\hline & $\begin{array}{l}\text { Abnormal } \\
\text { cytokinesis }\end{array}$ & & - & & - & & 9 & & - \\
\hline & Divergent spindle & & 14 & & - & & - & & 192 \\
\hline \multirow[t]{2}{*}{ AII } & $\begin{array}{l}\text { Laggard } \\
\text { chromosomes }\end{array}$ & 28 & 11 & 69 & 48 & 93 & 34 & 26 & 2 \\
\hline & Divergent spindle & & 4 & & - & & - & & 22 \\
\hline \multirow{3}{*}{ TII } & Micronuclei & 151 & 88 & 203 & 109 & 94 & 21 & 34 & 3 \\
\hline & $\begin{array}{l}\text { Chromosome } \\
\text { stickiness }\end{array}$ & & 2 & & - & & - & & 26 \\
\hline & Divergent spindle & & 14 & & - & & - & & - \\
\hline \multirow{3}{*}{$\mathrm{T}$} & Micronuclei & 537 & 281 & 1148 & 670 & 702 & 142 & 237 & 86 \\
\hline & Microcytes & & 16 & & 1 & & 12 & & 13 \\
\hline & Polyads & & 24 & & - & & 18 & & 23 \\
\hline \multicolumn{2}{|c|}{ Total (\%) } & 2457 & $\begin{array}{r}1366 \\
(55.6)\end{array}$ & 3147 & $\begin{array}{c}1521 \\
(48.3)\end{array}$ & 3051 & $\begin{array}{c}556 \\
(18.2)\end{array}$ & 2374 & $\begin{array}{r}1095 \\
(46.1)\end{array}$ \\
\hline
\end{tabular}

* MI: metaphase I; AI: anaphase I; TI: telophase I; PII: prophase II; MII: metaphase II; AII: anaphase II; TII: telophase II; T: tetrad. ** PMCs: pollen mother cells.

tion $d v$ which seriously compromises pollen fertility. From the two remaining sexual hybrids, only the HBGC324 should be kept in the program since it has high meiotic stability among cells.

\section{Acknowledgements}

Authors are grateful to UNIPASTO for financial support.

\section{References}

Adamowski, E.V.; Pagliarini, M.S.; Valle, C.B. 2008. Meiotic behaviour in three interspecific three-way hybrids between Brachiaria ruziziensis and B. brizantha (Poaceae: Paniceae). Journal of Genetics 87: 33-38.

Alonso, L.C.; Kimber, G. 1981. The analysis of meiosis in hybrids. II. Triploid hybrids. Canadian Journal of Genetics and Cytology 23: 221-234. 


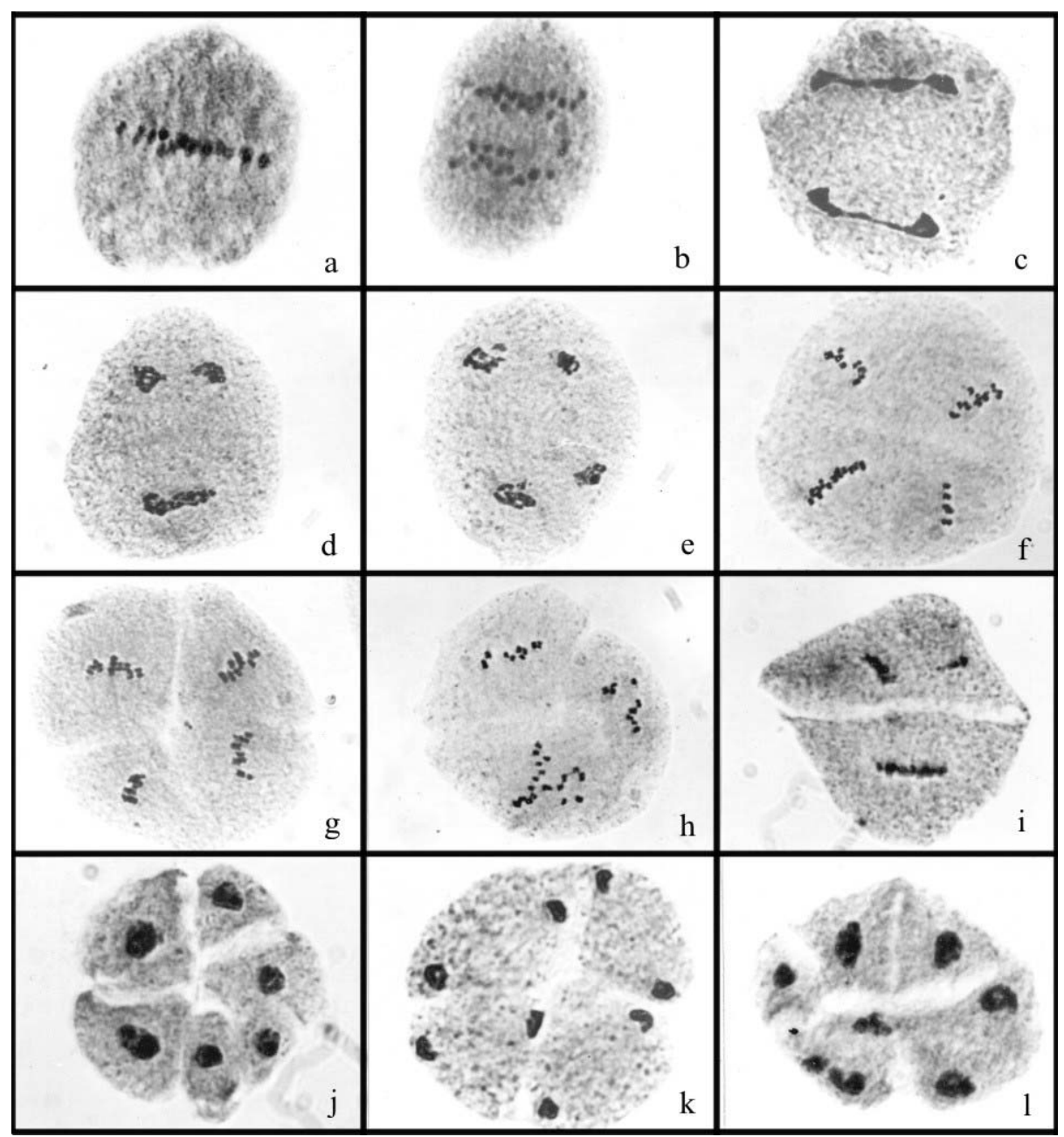

Figure 2 - Some aspects of the phenotypic expression of divergent spindle in HBGC313 and HBGC325. a) Metaphase I with a broad metaphase plate. b) Anaphase I with non-convergent chromosomes to the poles. c) Telophase I with two elongated nuclei. d, e) Telophase I with bipartite nuclei. f, g) Metaphase II with four metaphase plates with different numbers of chromosomes in each one resulting from bipartition of both telophase I nuclei. h, i) Metaphase II with three metaphase plates with different numbers of chromosomes resulting from bipartition of one telophase I nucleus. j, k) Telophase II with eight nuclei resulting from bipartition of both telophase I nuclei. 1) Telophase II with six nuclei resulting from bipartition of one telophase I nucleus. (400X).

Alves, E.R.; Carneiro, V.T.C.; Araújo, A.C.G. 2001. Direct evidence of pseudogamy in an apomictic Brachiaria brizantha (Poaceae). Sexual Plant Reproduction 14: 207-212.

Araújo, A.C.G.; Mukhambetzhanov, S.; Pozzobon, M.T.; Santana, E.F.; Carneiro, V.T.C. 2000. Female gametophyte development in apomictic and sexual Brachiaria brizantha (Poaceae). Revue de Cytologie et de Biologie Vegetales - Le Botaniste 23: 13-28.

Barbosa, R.A. 2006. Morte de Pastos de Braquiárias. Embrapa Gado de Corte, Campo Grande, MS, Brazil.

Clark, F.J. 1940. Cytogenetic studies of divergent meiotic spindle formation in Zea mays. American Journal of Botany 27: 547-559.

Fuzinatto, V.A.; Pagliarini, M.S.; Valle, C.B. 2007. Microsporogenesis in sexual Brachiaria hybrids (Poaceae). Genetics and Molecular Research 6: 1107-1117.

Gale, M.D.; Miller, T.E. 1987. The introduction of alien genetic variation into wheat. p. 173-210. In: Lupton, F.H., ed. Wheat breeding: its scientific basis. Chapman and Hall, London, UK.

Gobbe, J.; Swenne, A.; Louant, B.P. 1981. Diploïdes naturels et autotétraploïdes induits chez Brachiaria ruziziensis Germain et Evrard: critères d'identification. L'Agronomie Tropicale 36: 339-346.
Hopkinson, J.M.; Souza, F.H.D.; Diulgheroff, S.; Ortiz, A.; Sánchez, M. 1996. Reproductive physiology, seed production, and seed quality of Brachiaria. p. 124-140. In: Miles, J.W.; Maass, B.L.; Valle, C.B., ed. Brachiaria: biology, agronomy, and improvement, CIAT/Embrapa, Brasília, DF, Brazil.

Lutts, S.; NdikumanA, J.; Louant, B.P. 1991. Fertility of Brachiaria ruziziensis in interspecific crosses with Brachiaria decumbens and Brachiaria brizantha: meiotic behavior, pollen viability, and seed set. Euphytica 57: 267-274.

Mendes-Bonato, A.B.; Pagliarini, M.S.; Valle, C.B.; Penteado, M.I.O. 2001a. A severe case of chromosome stickiness in pollen mother cells of Brachiaria brizantha (Hochst) Stapf (Gramineae). Cytologia 6: 287-291.

Mendes-Bonato, A.B.; Pagliarini, M.S.; Valle, C.B.; Penteado, M.I.O. 2001b. Meiotic instability in invader plants of signal grass Brachiaria decumbens Stapf (Gramineae). Acta Scientiarum 23: 619-625

Mendes-Bonato, A.B.; Junqueira Filho, R.G.; Pagliarini, M.S.; Valle, C.B.; Penteado, M.I.O. 2002a. Unusual cytological patterns of microsporogenesis in Brachiaria decumbens: abnormalities in 
spindle and defective cytokinesis causing precocious cellularization. Cell Biology International 26: 641-646.

Mendes-Bonato, A.B.; Pagliarini, M.S.; Forli, F.; Valle, C.B.; Penteado, M.I.O. 2002b. Chromosome number and microsporogenesis in Brachiaria brizantha (Gramineae). Euphytica 125: 419-425.

Miles, J.W.; Valle, C.B. 1996. Manipulation of apomixis in Brachiaria breeding. p. 164-177. In: Miles, J. W.; Maass, B.L.; Valle, C.B., eds. Brachiaria: Biology, Agronomy, and Improvement. CIAT/ Embrapa, Brasília, DF, Brazil.

Miles, J.W.; Maass, B.L.; Valle, C.B. 1996. Brachiaria: Biology, Agronomy, and Improvement. CIAT/Embrapa, Brasília, DF, Brazil..

Miles, J.W.; Valle, C.B.; Rao, I.M.; Euclides, V.P.H. 2004. Brachiariagrasses. p. 745-760. In: Sollenberger, L.E.; Moser, L.E.; Burson, B.L., eds. Warm-season (C4) grasses. ASA, CSSA, SSSA, Madison, MI, USA.

Rao, I.M.; Kerridge, P.C.; Macedo, M.C.M. 1996. Nutritional requeriments of Brachiaria and adaptation to acid soils. p. 5371. In: Miles, J.W.; Maass, B.L.; Valle, C.B., eds. Brachiaria: biology, agronomy, and improvement, CIAT/Embrapa, Brasília, DF, Brazil.

Renvoize, S.A.; Clayton, W.D.; Kabuye, C.H.S. 1996. Morphology, taxonomy, and natural distribution of Brachiaria (Trin.) Griseb. p. 1-15. In: Miles, J.W.; Maass, B.L.; Valle, C.B., eds. Brachiaria: biology, agronomy, and improvement, CIAT/Embrapa, Brasília, DF, Brazil.

Rieseberg, L.H.; Baird, S.J.E.; Gardner, K.A. 2000. Hybridization, introgression, and linkage evolution. Plant Molecular Biology 42: 205-224

Risso-Pascotto, C.; Pagliarini, M.S.; Valle, C.B. 2005a. Meiotic behavior in interspecific hybrids between Brachiaria ruziziensis and Brachiaria brizantha (Poaceae). Euphytica 145: 155-159.
Risso-Pascotto, C.; Pagliarini, M.S.; Valle, C.B. 2005b. Multiple spindles and cellularization during microsporogenesis in an artificially induced tetraploid accession of Brachiaria ruziziensis (Gramineae). Plant Cell Reports 23: 522-527.

Savidan, Y.H. 2000. Apomixis: genetics and breeding. Plant Breeding Review 18: 13-86.

Shamina, N.; Dorogova, N.; Trunova, S. 2000. Radial spindle and the phenotype of the maize meiotic mutant, $d v$. Cell Biology International 24: 729-736.

Staiger, C.J.; Cande, W.Z. 1990. Microtubule distribution in $d v$, a maize meiotic mutant defective in the prophase to metaphase transition. Development Biology 138: 231-242.

Swenne, A.; Louant, B.P.; Dujardin, M. 1981. Induction par la colchicine de formes autotétraplö̈des chez Brachiaria ruziziensis Germain et Evrard (Gramínée). L'Agronomie Tropicale 36: 134 141.

Utsunomiya, K.S.; Pagliarini, M.S.; Valle, C.B. 2005. Microsporogenesis in tetraploid accessions of Brachiaria nigropedata (Ficalho and Hiern) Stapf (Gramineae). Biocell 29: 295-301.

Valle, C.B.; Savidan, Y.H. 1996. Genetics, cytogenetics, and reproductive biology of Brachiaria.p. 147-163. In: Miles, J.W.; maass, B.L.; Valle, C.B., eds. Brachiaria: biology, agronomy, and improvement. CIAT/Embrapa, Brasília, DF, Brazil.

Young, B.A.; Sherwood, R.T.; Bashaw, E.C. 1979. Cleared-pistyl and thick-sectioning techniques for detecting aposporous apomixis in grasses. Canadian Journal of Botany 57: 1668-1672.

Received March 09, 2009

Accepted November 03, 2009 